\title{
THE EFFECT OF STOCK OPTION COMPENSATION ON EARNINGS MANAGEMENT WITH CORPORATE GOVERNANCE AND AUDIT QUALITY AS MODERATING VARIABLES
}

\author{
Arlita I G.A. Desy*, Wirama Dewa Gede \\ Faculty of Economy and Business, University of Udayana, Indonesia \\ *E-mail: arlitadesy0403@gmail.com
}

\begin{abstract}
Agency theory stated that stockholders must establish contractual relationships to provide reasonable compensation for managers to make decisions that maximize shareholder value even in uncertain situations and imperfect monitoring. One of them is stock option compensation. According to positive accounting theory, stock options compensation increase earnings management. The inconsistency of previous study encourages research by adding corporate governance and audit quality as moderating variables. The results prove the tendency of theory that occurs in business practices and provide input for policy makers to suppress earnings management. The sample consists of 16 manufacturing companies in Indonesian Stock Exchange with 81 observation data taken by purposive sampling. Earnings management is measured by real earnings management. Stock option compensation and audit quality with dummy while corporate governance is measured by corporate governance disclosure index. Hypothesis testing was performed using moderated regression analysis. The result of the study proves that stock option compensation has a positive effect on earnings management. Corporate governance reinforces the effect of stock option compensation on earnings management. Audit quality does not moderate the effect of stock option compensation on earnings management. Based on this result, companies should use other incentive plan to reduce earnings management. Practitioners and governments also need to reevaluate corporate governance requirements in order to protect stockholders not only from accrual earnings management but also real earnings management. The auditor profession is advised to continue to develop methods that can detect real earnings management.
\end{abstract}

\section{KEY WORDS}

Agency theory, positive accounting theory, earnings management, stock option compensation, corporate governance, audit quality.

The separation between owner and management in a public company resulted in an agency relationship within the company. This agency relationship resulted in issues related to the separation of control and ownership in the company (Jensen and Meckling, 1976). This agency problem can ultimately lead to opportunistic management behavior in the form of earnings management practices. One example of harmful earnings management practices happening in Toshiba.

In May 2015 Toshiba first announced that the company was investigating an accounting scandal that could lead to a revision of the company's profit over the past three years (Ando et al., 2015). Toshiba has inflated earnings of USD 1.2 billion over the previous seven-year period (CNN, 2015). As a result of this accounting scandal Toshiba shares fell to a two-and-a-half-year low and a net loss for the quarterly period of 12.3 billion yen (BBC News, 2015).

The earnings management can be detrimental so stockholders must find a way to develop the right contractual relationship. Jensen and Murphy (1990) recommend that compensation policies be designed to encourage managers to choose and implement actions that increase shareholder value even in uncertain situations and imperfect monitoring. One of them is with stock option compensation. The most important reason 
managers today have a relatively large stock-based compensation package is to align manager goals with the goals of interested parties (Vos, 2010).

On the other side, according to the bonus plan hypothesis in positive accounting theory, compensation actually increases opportunistic behavior. On this theory it is assumed the manager will maximize their personal benefits (Watts and Zimmerman, 1978). Sun (2012) states that executive compensation contracts are incentives where opportunistic behavior in the form of earnings management tends to be detected because CEO allegedly have the drive to manage earnings if executive compensation is strongly attributed to performance. This is supported by the results of Alves (2012) and Lakhal et al. (2014) found that stock option compensation had a positive effect on earnings management. In addition, Kadan and Yang (2016) also found that the money value of new stock options is given and cumulative share returns are strongly correlated with earnings management.

Contrary, Essid (2012) found that the Executive Stock Option (ESO) lowers earnings management and is an additional control mechanism. Hassen (2014) found that total stock compensation is negatively related to the absolute value of accruals. Farichah (2017) also stated that there is a negative relationship of management compensation on earnings management.

The inconsistency of previous research results is presumed to be due to moderating variables that weaken or reinforce the effect of stock option compensation on earnings management. This study was conducted to re-examine the effect of stock option compensation on earnings management by adding moderation variables namely corporate governance and audit quality. Research Lakhal et al. (2014) found that stock option compensation has a positive effect on earnings management suggests research on the role of corporate governance in moderating the effect of stock option compensation on earnings management. Research Ahmad et al. (2016) that was conducted on manufacturing companies in Indonesia shows that companies that are audited by big-four will be less involved in earnings management than unaudited companies by big-four. So it is assumed that a good audit quality will moderate the effect of stock option compensation on earnings management.

This study was conducted to determine the effect of stock options compensation on earnings management and to know the ability of corporate governance and audit quality in moderating the effect of stock option compensation on earnings management. This study also aims to find a mechanism that can reduce the negative impact of the effect of stock option compensation on improving earnings management so that agency costs can be reduced.

\section{LITERATURE REVIEW}

The agency relationship is a contract between two or more persons, between a principal against a person called an agent, in order for the agent to act in a principal name that includes the delegation of some decision-making authority (Jensen and Meckling, 1976). Management as an agent has the responsibility to optimize shareholder profits and in return the management will be compensated according to the contract (Jensen and Meckling, 1976). In this relationship can be found a conflict.

Agency conflict is an act of individualism between the two parties to be more selfish than the interests of the company. The owner of a company as principal focuses on stock price hikes while management will focus on self-interest so that it tends to make unilateral policies that can harm the company (Hidayanti and Laksito, 2013).

Managers of the company have more information than stockholders as owners of the company resulting in an imbalance of ownership of information. The presence of asymmetric information and conflict of interest poses agency problems so that the company must bear agency costs.

Positive accounting theory is a branch of accounting research that seeking explanations and predicting actual accounting practices. Positive accounting can be attributed to the company's contractual views (Coase, 1937 and Jensen and Meckling, 1976). 
In the company's view as the nexus of contract, accounting practices evolve to reduce contract costs by establishing agreements among various parties.

There are three hypotheses that show the manager's motive for choosing an accounting method over other methods: Bonus Plan Hypothesis, Debt Hypothesis, and Political Cost Hypothesis (Watts and Zimmerman, 1978). Managers with incentives that are associated with a firm's accounting performance tend to manage accounting methods and figures to show better accounting performance (Deegan, 2009).

Schipper (1989) in Wolk et al (2001) defines earnings management as a deliberate intervention in external financial reporting in order to gain personal benefit. Earnings management occurs when managers use judgments in financial reporting and transaction preparation to alter financial statements so as to mislead some stakeholders about the firm's economic performance or to influence contract yields that depend on the amount of accounting reported (Healy and Wahlen, 1999).

The company's board of commissioners tries to establish an optimal incentive compensation scheme to reduce agency costs (Essid, 2012). The incentive compensation scheme will establish a self-monitoring system and align the interests of shareholders and managers (Dorff, 2005). This stock option compensation is commonly used as a means to increase executive loyalty and motivation by making them as company owners and to add executive income as additional compensation (Asyik, 2010).

Sun (2012) concludes that executive compensation contracts are an incentive where opportunistic behavior in the form of earnings management tends to be detected because of the CEO. This means that giving stock option compensation encourages managers to be opportunistic by doing earnings management. Alves (2012) and Lakhal et al. (2014) found that stock option compensation has a positive effect on earnings management. The same is also evidenced by Kadan and Yang (2016) who found that the money value of the new stock option is given and the cumulative share return is strongly correlated with earnings management and insider trading in vesting years.

Corporate governance is a process and structure used by corporate organs, directors, managers, shareholders, and parties related to the development of the company in certain environments, to improve business success and corporate accountability in order to increase shareholder value in the long term by taking into account other stakeholders based on legislation and ethical values (Sutedi, 2011).

Corporate governance initially emerged to suppress conflicts of interest between management and stockholders resulting from the separation of ownership and control (Baydoun et al., 2012). Abbadi et al. (2016) states the agency theory framework suggests that internal oversight mechanisms help ensure that directors implement policies that maximize shareholder value. Corporate governance can mitigate the opportunistic behavior of managers in manipulating reported earnings (Nazira and Afza, 2018).

Auditing is a form of monitoring that companies use to reduce agency costs with creditors and shareholders (Jensen and Meckling, 1976). Independent auditor participation is an important part in reducing opportunistic managerial behavior (Saleem and Alzoubi, 2016). Ahmad et al. (2016) suggests that Indonesia's audited manufacturing firms Big four will be less involved in earnings management than unaudited by big four.

\section{METHODS OF RESEARCH}

This study analyzes the effect of stock option compensation on earnings management with corporate governance and audit quality as a moderating variable with the research framework that shown in Figure 1.

Based on literature review and research framework, hypotheses are stated as follow:

$\mathrm{H}_{1}$ Stock option compensation has a positive effect on earnings management;

$\mathrm{H}_{2}$ Corporate governance moderates the effect of stock option compensation on earnings management;

$\mathrm{H}_{3}$ Audit quality moderates the effect of stock option compensation on earnings management. 


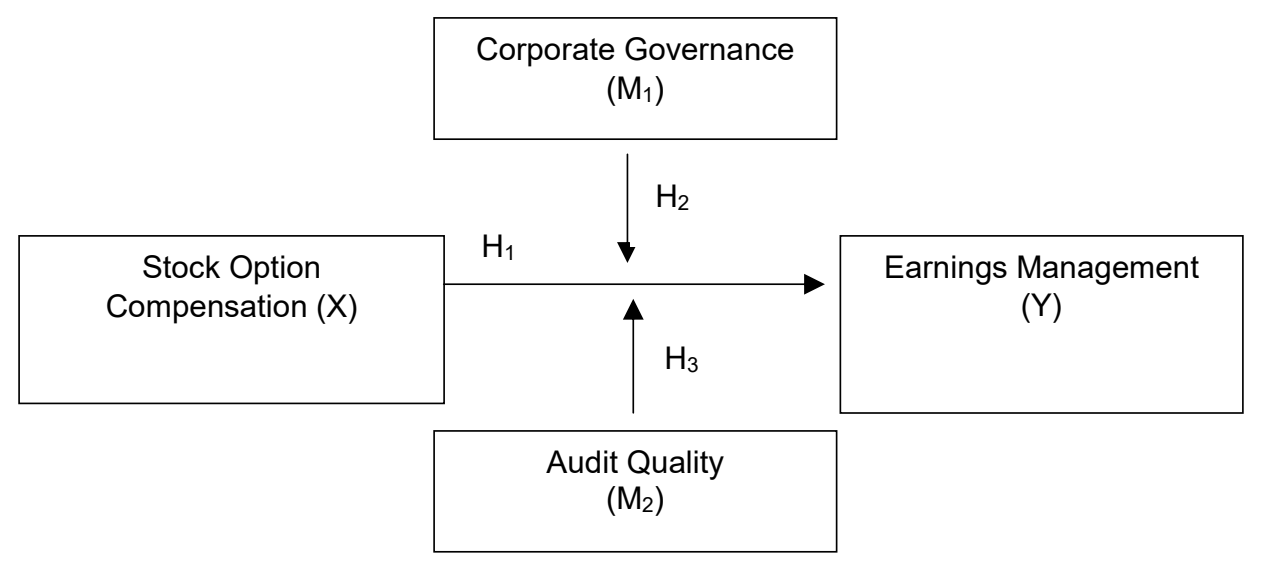

Figure 1 - Research Framework

The research was conducted at a manufacturing company in Indonesia Stock Exchange with data from 2018 to 2016. Manufacturing companies were selected because Subekti (2012) proves that the management of companies in Indonesia tends to make real earnings management in manufacturing companies. Observation period starts from 2008 because this year there is a global crisis that makes the bad economic conditions that trigger the occurrence of earnings management. One example is Toshiba, who performed a sevenyear earnings management, where the scandal was revealed in 2015. Wang (2014) also proves that real earnings management tends to be higher in poorer economies.

Sampling method using purposive sampling technique with criteria as follows:

- The Company has a stock option compensation program or has an average value of the number of assets close to the company that has stock options in the same subsector;

- The Company has issued annual reports for the period of the year under review and has been audited by an independent auditor;

- The Company has all the necessary data on research such as cash flow from operating activities, total assets, sales, cost of goods sold, and operating expenses.

Based on these criteria, there were 16 companies with 81 observation data. Data obtained from www.idx.co.id, IDX representative office in Denpasar, each company's website, and archives available at www.morningstar.com.

Earnings management is the dependent variable in this study which is proxied with real earnings management calculated according to estimation model by Roychowdhury (2006) as follows:

- The cash flow abnormality rate of the operating activity (CFO) is calculated by subtracting actual CFO to normal CFO calculated by using the estimated coefficient of the following models:

$$
\mathrm{CFO}_{\mathrm{t}} / \mathrm{A}_{\mathrm{t}-1}=\alpha_{0}+\alpha_{1}\left(1 / \mathrm{A}_{\mathrm{t}-1}\right)+\beta_{1}\left(\mathrm{~S}_{\mathrm{t}} / \mathrm{A}_{\mathrm{t}-1}\right)+\beta_{2}\left(\Delta_{\mathrm{S}} / \mathrm{A}_{\mathrm{t}-1}\right)+\varepsilon_{\mathrm{t}}
$$

Where: $\mathrm{CFO}_{t}$ - cash flow from operating activities in period $t ; A_{t}$ - Total assets at the end of period $\mathrm{t}$; $\mathrm{S}_{\mathrm{t}}$ - sales during period $\mathrm{t} ; \Delta \mathrm{S}_{\mathrm{t}}$ - sales period $\mathrm{t}$ minus sales period $\mathrm{t}-1$.

- The abnormality of production costs (PROD) is calculated by subtracting the actual production cost from the normal production cost calculated using the estimated coefficient of the following models:

$$
\operatorname{PROD}_{t} / A_{t-1}=\alpha_{0}+\alpha_{1}\left(1 / A_{t-1}\right)+\beta_{1}\left(S_{t} / A t_{-1}\right)+\beta_{2}\left(\Delta S_{t} / A_{t-1}\right)+\beta_{3}\left(\Delta S_{t-1} / A_{t-1}\right)+\varepsilon_{t}
$$

Where: PRODt - production cost in period $t ; A_{t}$ - Total assets at the end of period $t ; S_{t}-$ sales during period $\mathrm{t} ; \Delta \mathrm{S}_{\mathrm{t}}$ - sales period $\mathrm{t}$ minus sales period $\mathrm{t}-1 ; \Delta \mathrm{S}_{\mathrm{t}-1}$ - sales period $\mathrm{t}-1$ minus sales period $\mathrm{t}-2$. 
- The discretionary cost abnormality rate (DISEXP) is calculated by subtracting the actual discretionary cost at normal discretionary cost calculated using the estimated coefficient of the following models:

$$
\operatorname{DISEXP} \mathrm{t}_{\mathrm{t}} / \mathrm{A}_{\mathrm{t}-1}=\alpha_{0}+\alpha_{1}\left(1 / \mathrm{A}_{\mathrm{t}-1}\right)+\beta\left(\Delta \mathrm{S}_{\mathrm{t}-1} / \mathrm{A}_{\mathrm{t}-1}\right)+\varepsilon_{\mathrm{t}}
$$

Where: DISEXP $P_{t}$ production cost in period $t ; A_{t}$ : Total assets at the end of period $t ; \Delta S_{t-1}$ : sales period $\mathrm{t}-1$ minus sales period $\mathrm{t}-2$.

After the three proxies were counted later as in Valikifard and Mortazavi (2016) study reversed scores were used for abnormal CFO and DISEXP so that for all three proxies, the higher residuals would be related to the management of high real activity. So real earnings management is:

$$
\text { REM }=\text { abnormalCFO * }(-1)+\text { abnormalDISEXP * }(-1)+\text { abnormalPROD }
$$

The independent variables of stock option compensation are measured using dummy, 1 for firms that compensate stock options and 0 for non-compensating stock options. Corporate governance is measured using the Corporate Governance Disclosure Index (IPCG) which assesses the implementation of corporate governance of a company based on the disclosure of corporate governance principles in its annual report. IPCG is built on Surifah research (2011).

Audit quality is measured using dummy variables. Companies whose financial statements are audited by the Public Accounting Firm affiliated with the Big Four are rated 1 while 0 for the reverse. Big-four in this study were Deloitte, PricewaterhouseCoopers, Ernst \& Young, and KPMG.

Hypothesis testing was performed using moderated regression analysis (MRA) with the following equation:

$$
\begin{aligned}
& Y=\alpha+\beta X+\varepsilon \\
& Y=\alpha+\beta_{2} M_{1}+\beta_{3} M_{2}+\varepsilon \\
& Y=\alpha+\beta_{4} X+\beta_{5} X^{*} M_{1}+\beta_{6} X^{*} M_{2}+\varepsilon
\end{aligned}
$$

Where: $Y$ - earnings management; $\alpha$ - constants; $\beta$ - regression coefficient; $X$ - stock option compensation; $M_{1}$ - corporate governance; $M_{2}$ - audit quality; $X{ }^{*} M_{1}$ - the interaction between stock option compensation and corporate governance; $X{ }^{*} M_{2}$ - the interaction between stock option compensation and audit quality; $\varepsilon$ - error term.

\section{RESULTS AND DISCUSSION}

The number of observation data of companies that have a share option compensation program of 21 data from 6 companies. The amount of observation data that the company's year report is audited by the Big Four as a better proxy for audit quality of 53 data. Descriptive statistics of the variables in this study are presented in Table 1 below.

Table 1 - Descriptive statistics

\begin{tabular}{|l|l|l|l|l|l|}
\hline Variables & $\mathrm{n}$ & Minimum & Maximum & Mean & Deviation Std \\
\hline Stock Option Compensation $(\mathrm{X})$ & 81 & 0,00 & 1,00 & 0,26 & 0,44 \\
\hline Corporate Governance $\left(\mathrm{M}_{1}\right)$ & 81 & 0,32 & 0,82 & 0,66 & 0,12 \\
\hline Audit Quality $\left(\mathrm{M}_{2}\right)$ & 81 & 0,00 & 1,00 & 0,65 & 0,48 \\
\hline Earnings Management $(\mathrm{Y})$ & 81 & $-2,00$ & 0,12 & $-0,50$ & 0,46 \\
\hline
\end{tabular}

From table 1 it is known that the average value of earnings management is -0.50 with the smallest value -2.00 and the highest value of 0.12 . The average value of earnings management is -0.50 and shows earnings management activity through real activity specially to increase profit in the manufacturing industry is relatively low. While the average value of corporate governance index is 0.66 with the highest value of 0.82 and the smallest 0.32 . The 
quality of audit has an average of 0.65 , which means that $65 \%$ of observational data are financial reports audited by the Big Four.

First regression equation results to see the effect of stock option compensation on earnings management. The results of the first equation regression can be seen in Table 2 below.

Table 2 - Equation (5) Regression Result

\begin{tabular}{|c|c|c|}
\hline Model & Regression Coef & Sig.t \\
\hline $\mathrm{X}$ & 0,218 & 0,025 \\
\hline \multicolumn{2}{|c|}{ Constanta } & 1,770 \\
\hline $\mathrm{R}^{2}$ & 0,047 \\
\hline
\end{tabular}

Based on Table 2 it can be concluded that the value of $\beta$ is 0.218 which means that stock option compensation has a positive relationship on earnings management. In other words, giving stock options compensation will improve earnings management. The option compensation variable has a significance value of 0.025 , a value less than 0.0505 so $\mathrm{H}_{1}$ accepted. Thus it is concluded that stock option compensation has a positive effect on earnings management.

Furthermore, multiple regression is done by incorporating corporate governance (M1) and audit quality (M2) with regression result presented in Table 3 below.

Table 3 - Equation (6) Regression Result

\begin{tabular}{|c|c|c|}
\hline Model & Regression Coef & Sig.t \\
\hline $\mathrm{X}$ & 0,228 & 0,004 \\
\hline $\mathrm{M}_{1}$ & 0,549 & 0,002 \\
\hline $\mathrm{M}_{2}$ & $-0,038$ & 0,684 \\
\hline \multicolumn{2}{|c|}{} & $-5,595$ \\
\hline & Constanta & 0,344 \\
\hline
\end{tabular}

Based on Table 3 it can be seen that stock option compensation has a regression coefficient of 0.228 which means the compensation of stock options will increase the occurrence of earnings management. In addition, the coefficient of corporate governance regression and audit quality of 0.549 and -0.036 , respectively, also means that the better the implementation of corporate governance the higher the actual earnings management practices that occur otherwise, on audit quality, the higher the audit quality owned by the company will result in real earnings management become lower. From Table 5.5 it is also known that corporate governance has a significance value of 0.002 while the audit quality is 0.684 .

Last done regression to build equation (3) by entering interaction effect of stock compensation and corporate governance compensation variable and interaction of stock option compensation with audit quality with regression result presented in Table 4 below.

Table 4 - Equation (7) Regression Result

\begin{tabular}{|c|c|c|}
\hline Model & Regression Coef & Sig.t \\
\hline $\mathrm{X}$ & $-1,853$ & 0,002 \\
\hline $\mathrm{XM}_{1}$ & 2,181 & 0,001 \\
\hline $\mathrm{XM}_{2}$ & $-0,078$ & 0,477 \\
\hline \multicolumn{2}{|c|}{} & 1,771 \\
\hline \multicolumn{2}{|r|}{} \\
\hline
\end{tabular}

Table 4 shows that the interaction between compensation of stock options and corporate governance has a regression coefficient of 2,181 which means that the higher interaction between stock option and corporate governance compensation can improve the behavior of real earnings management otherwise the higher interaction of stock option compensation and audit quality will decrease real earnings management. The significance 
value of stock options and corporate governance compensation is 0.001 , while the interaction of stock option compensation with audit quality is 0.477 .

The second hypothesis states that corporate governance moderates the effect of stock option compensation on earnings management. When viewed from the regression coefficient of share and corporate governance compensation interaction in Table 3 , it is seen that corporate governance actually strengthens the effect of compensation of the stock option on earnings management as reflected in positive regression coefficient value. Further testing is done by looking at the values of $\beta$ in equations (2) and (3). In equation (2) $\beta_{2}$ is significant and in regression model in equation (3) $\beta_{5} \mathrm{XM}_{1}$ it is known that $\beta_{5}$ is also significant so it can be concluded that variable $M_{1}$, corporate governance is quasi moderator. These results indicate that corporate governance moderates the effect of stock option compensation on earnings management so that $\mathrm{H}_{2}$ is accepted.

The third hypothesis states that audit quality moderates the effect of stock option compensation on earnings management. Looking at the values of $\beta 3$ in equations (2) and (3). In equation (3) $\beta_{3}$ is not significant and in the regression model in equation (3) $\beta_{6} X M_{2}$ it is known that $\beta_{6}$ is also not significant it can be concluded that variable $M_{2}$, audit quality is homologiser moderator variable. Hence it is concluded that $\mathrm{H}_{3}$ is rejected, which means that audit quality does not moderate the effect of stock option compensation on earnings management.

Judging from the regression results in Tables 1,2 , and 3 , there is a change in the coefficient of determination. When the model only takes into account the effect of stock option compensation on earnings management, the value of $R^{2}$ is 0.047 , which means stock options compensation can affect earnings management only by $4.7 \%$ while the rest of $95.3 \%$ is influenced by other factors not found in the model. After added the corporate governance and audit quality variables, the value of $R^{2}$ becomes 0.344 which means that jointly compensation stock options, corporate governance, and audit quality can affect earnings management by $34.4 \%$ while the rest of $65.6 \%$ is influenced by other variables which did not become the focus of the study. In the third model the value of $R^{2}$ becomes 0.323 , which means compensation of stock options and its interaction with corporate governance and audit quality can only affect earnings management of $32.3 \%$.

\section{DISCUSSION OF RESULTS}

The results of the first hypothesis test show that stock option compensation has a positive effect on earnings management. These results support the research of Alves (2012) and Lakhal et al. (2014) and Kadan and Yang (2016) found that stock option compensation has a positive effect on earnings management.

Psychologically, management as a shareholder wants its stock options to have potential profitable value, which can be gained by improving performance or performing earnings management (Mukhtar and Taqwa, 2016). This research proved that management decided to make earnings management to reach the potential value that cater from stock options owned. It is in the opinion of Alves (2012) that the option of executive stock increases the opportunistic scope of the manager.

This study supports the positive accounting theory disclosed Watts and Zimmerman (1978), a bonus scheme hypothesis states that the bonus given to management will precisely encourage management to behave opportunistically by doing earnings management. Compensation will encourage managers to manage accounting methods and figures to show better accounting performance (Deegan, 2009). This study is also consistent with result of Sun (2012) which is executive compensation contracts are an incentive where opportunistic behavior in the form of earnings management tends to be detected. This means that giving stock option compensation encourages managers to be opportunistic by doing earnings management.

Results of this study prove that stock option compensation is not an effective mechanism to reduce earnings management, but the provision of stock option compensation 
will actually encourage opportunistic behavior management so that earnings management is increasing.

The second hypothesis in this study is accepted which means that corporate governance moderates the effect of stock option compensation on earnings management. Nevertheless, the results of research show the opposite direction, corporate governance actually strengthens the effect of stock options compensation on earnings management. This implies the implementation of corporate governance disclosed in the annual report rather than undermining earnings management behavior but rather encouraging earnings management.

The results of this study contradict Abbadi (2016) that shows that good corporate governance quality will decrease earnings management. Corporate governance in this study actually improve earnings management so it can be concluded that the implementation of corporate governance is not effective in suppressing the opportunistic behavior of management in the form of earnings management. On the contrary, corporate governance actually strengthens the occurrence of earnings management resulting from the compensation of stock options and even corporate governance is directly proven to have a positive effect on earnings management. In this research, it is proved that corporate governance is a quasi moderator variable affecting earnings management as independent variable as well as moderation variable.

Corporate governance improves earnings management especially real earnings management. This is in line with the results of research Eny et al. (2015), which proves the greater percentage of institutional ownership, managerial ownership, the proportion of independent commissioners, and the existence of audit committees leads to higher levels of earnings management through real activity in the enterprise. This result is also supported by Istianingsih (2016) who found that the implementation of corporate governance has a positive effect on earnings management as measured by real activity.

Corporate governance can improve earnings management because in measurements there is a compensation that is the concentration of institutional ownership, the existence of remuneration committees, board meetings and commissioner sizes, as evidenced in some studies actually improve earnings management, particularly real earnings management.

Ming and Shiow (2015) found that the higher the concentration of institutional ownership, the manager tends to increase production costs which means improving real earnings management. This finding is also supported by Fauziyah (2017) found that institutional ownership actually improves the management of real activities undertaken by the company.

The institution as a shareholder also has an interest in the company's profits. Indonesian statement of accounting standard, PSAK 15 provides that if the company owns a share of more than $20 \%$ then the investment reporting must use the equity method. This method requires the investor's share of the income of the investee to be recognized in the profit and loss of the investor so that the earnings of the investee will increase the profit for the investor. This is suspected to be the cause of institutional owners also tend to support earnings management.

The existence of the remuneration committee is proved to have a positive effect by Obigbemi et al. (2016) this raises the question of the indentation and composition of the remuneration committee. Obigbemi et al. (2016) also found that firms with higher frequency of board meetings exhibit higher earnings management trends. Limanto and Herusetya (2017) research proves that the size of the board of commissioners improves earnings management when the company has transactions with related parties. This is supposedly because the board of commissioners can engage with related party transactions at a strategic level to improve the company's performance by making earnings management on the company's real activities.

This study measures corporate governance with scorecard assessments that use indicators that turn out to be higher the score obtained actually improve the practice of earnings management. Corporate governance is a mechanism designed to provide protection for investors, Enomoto et al. (2015) finds that managers in countries with stronger 
investor protection tend to exercise real earnings management rather than accrual-based earnings management. This result is also supported by Istianingsih (2016) which proves that corporate governance index is not proven able to dampen earnings management practices in Indonesia because it only leads to trade off of earnings management through income discretion to earnings management through real activity.

This study was conducted with the proxy of real earnings management so that it is in accordance with the findings of Enomoto et al. (2015) and Istianingsih (2016), the implementation of good corporate governance improves earnings management while strengthening the effect of stock options compensation on earnings management. In other words, the behavior of the positive effect of stock options compensation on earnings management tends to occur in companies that have high quality corporate governance.

The third hypothesis in this study is rejected, which means that audit quality does not moderate the effect of stock option compensation on earnings management. This result conflicts with the assumption that audits performed by higher quality auditors can detect earnings management by management and report them so that earnings management behavior can be suppressed. Thus the results of this study are inconsistent with Saleem and Albazouni (2016) and Ahmad et al. (2016) which states that the quality of auditor's proxies by the Big Four audit will be less involved in earnings management practices.

The Professional Standards of Certified Public Accountants (SPAP) have regulated fraud in an audit of financial statements on Audit Standards 240: "The Responsibility of an Auditor Associated with Fraud in an Audit of a Financial Statement". The auditor should obtain reasonable assurance whether the overall financial statements are free from material misstatement, caused by fraud or error. Because of the inherent limitations of an audit, there is always an inevitable risk that some material misstatement in the financial statements may not be detected, even though the audit has been well planned and executed (Hidayah, 2016).

Real earnings management through real corporate activity will be more difficult to detect by the auditor. This is in accordance with the results of research Cheong et al. (2015) stating that when accrual-based earnings management is controlled, audit quality no longer affects the quality of financial statements because auditors will find it more difficult to detect earnings management practices through the real activities of the company so there is no difference in audit quality between Big Four and non-Big Four. Consequently, the quality of the auditor cannot decrease the real earnings management ploy. So auditor quality cannot be an effective tool to help reduce the occurrence of earnings management practices that occur when the company has a stock option compensation program.

\section{CONCLUSION}

Based on the results and discussions that have been done then concluded the following:

- Stock option compensation has a positive effect on earnings management. The results of this study support the bonus plan hypothesis on positive accounting theory with the finding that stock option compensation increases earnings management practices.

- Corporate governance is a quasi moderator variable that reinforces the effect of stock options compensation on earnings management. This means that an implementation disclosure of corporate governance increase earnings management while strengthening the effect of stock options compensation on earnings management.

- Audit quality does not moderate the effect of stock option compensation on earnings management.

This study has limitations in the number of samples because the number of manufacturing companies in the BEI which has a stock option compensation program is still very small. If similar research is to be done, research can be focused on looking at whether or not there is a difference in earning management practices before and after stock option compensation. In addition, research can be done on other industries whose members more 
compensate stock options such as companies in the financial sector. Due to the different characteristics of the company's operations, other studies can also be made to build adequate measures to measure earnings management practices in other industries.

\section{REFERENCES}

1. Abbadi, S,S., Hijazi, Q, F., Al-Rahahleh, A, S. 2016. Corporate Governance Quality and Earnings Management: Evidence from Jordan. Australasian Accounting, Business and Finance Journal, 10(2): 54-75.

2. Ahmad, L., Suhara, E., llyas, Y. 2016. The Effect of Audit Quality on Earning Management within Manufacturing Companies Listed on Indonesian Stock Exchange. Research Journal of Finance and Accounting, 7(8): 132-138.

3. Alves, S. 2012. Executive Stock Options and Earnings Management in the Portuguese Listed Companies. Revista de Contabilidad, 15 (2): 211-235.

4. Ando, R., Sano, H., and Desai, U. 2015. Toshiba Eyes Three-Year Profit Markdown in Accounts Probe; Impact Seen Limited, Shares Up. Reuters, 14 Mei 2015., [accessed 18 Februari 2018] available at: URL: https://www.reuters.com/

5. Asyik, N,F. 2010. Executive Stock Option Plans: Uji Pengelolaan Laba selama Vesting Period. Ekuitas, 14(4): 478-500.

6. Baydoun, N., Maguire, W. Ryan, N., Willett, R. 2012, Corporate governance in five Arabian Gulf countries. Managerial Auditing Journal, 28(1): $7-22$.

7. BBC News. 2015. Toshiba Troubles Continue with New Losses and Falling Sales. BBC News, 14 September 2015., [accessed 20 February 2018] available at: URL: http://www.bbc.com/news/business-34244350.

8. Cheong, P.C., Boon, H.T., Ong, T.S. 2015. The Relationship among Audit Quality, Earnings Management, and Financial Performance of Malaysian Public Listed Companies. Int. Journal of Economics and Management, 9 (1): $211-229$.

9. Coase, R. 1937. The Nature of the Firm. Economica, 4: 386-405.

10. CNN. 2015. Toshiba CEO quits over $\$ 1.2$ billion accounting scandal. CNN News, 21 July 2015., [accessed 20 February 2018]. Available at: URL: https://www.youtube.com/

11. Deegan, C. M. 2009. In Financial Accounting Theory. North Ryde, N.S.W: McGraw-Hill.

12. Dorff, B. 2005. 'Does One Hand Wash The Other? Testing The Managerial Power and Optimal Contracting Theories of Executive Compensation. Journal of Corporation Law, 30(2): 255-307.

13. Eny, K., Trisnawati, R., Mardalis, A. 2015. Pengaruh Corporate Governance terhadap Manajemen Laba Riil. The 2nd University Research Coloquium.

14. Essid, W. 2012. Executive Stock Options and Earnings Management: is there an Option Level Dependence? Corporate Governance, 12(1): 54-70.

15. Farichah, F. 2017. Management Compensation and Auditor Reputation on Earnings Management and on Share Returns. European Research Studies Journal, 20(3A): 196208.

16. Fauziyah, N. 2017. Pengaruh Good Corporate Governance Dan Leverage Terhadap Manajemen Laba Melalui Pengelolaan Aktivitas Riil Pada Perusahaan Manufaktur Yang Terdaftar Di Bursa Efek Indonesia Periode 2010-2012. Jurnal Profita, 2:1-14.

17. Hassen, R. B. 2014. Executive Compensation and Earning Management. International Journal of Accounting and Financial Reporting, 4(1): 84-105.

18. Healy, P. M., Wahlen, J.M. 1999. A Review of the earnings management literature and its implications for standard setting. Accounting Horizons, 13(4): 355-383.

19. Hidayah, D.N. 2016. Seberapa Jauh Tanggung Jawab Auditor terkait dengan Kecurangan dalam Laporan Keuangan? 2 Agustus 2016., [diakses 20 Mei 2018] Tersedia dari: URL: http://jtanzilco.com/

20. Hidayanti, A.N,. Laksito,H. 2013. Pengaruh antara Kepemilikan Keluarga dan Corporate Governance terhadap Tindakan Pajak Agresif. Diponogoro Journal of Accounting, 2(2) 
21. Istianingsih. 2016. Deteksi Manajemen Laba Melalui Discretionary Revenue dan Aktifitas Riil: Implikasi Penerapan Good Corporate Governance. Jurnal Riset Akuntansi dan Keuangan, 4 (3): 1125-1142.

22. Jensen, M, J., Meckling, W, H. 1976. Theory of Firm: Managerial Behaviour, Agency Cost and Ownership Structure. Journal of Financial Economic, 3(4): 305-360.

23. Jensen, M.C., Murphy, K. 1990. 'Performance and top management incentives. Journal of Political Economy, 98(2): 225-64.

24. Kadan, O., Yang, J. 2016. Executive Stock Options and Earning Management: A theoretical and Empirical Analysis. Quarterly Journal of Finance, 6(2): 1650003 (1-39).

25. Lakhal, F., Lakhal, N., Cheurfi, S. 2014. Does Pay for Performance Reduce Earnings Management in France? European Journal of Business and Management, 6(13): 49-57.

26. Limanto, G.K., Herusetya, A. 2017. The association between related party transactions and real earnings manajemen: internal governance mechanism as moderating variabel. SHS Web of Conferences 34, 04008.

27. Ming, F. H., Shiow, Y.W. 2015. The Influence Of Corporate Governance In Chinese Companies On Discretionary Accruals And Real Earnings Management. Asian Economic and Financial Review, 5(3): 391-406.

28. Mukthar, N., Taqwa, S. 2016. Pengaruh Earning Power, Kecakapan Manajerial, Dan Employess Stock Ownership Program Terhadap Manajemen Laba Riil: Studi Empiris pada Perusahaan Manufaktur yang terdaftar di BEI tahun 2010-2014. Jurnal WRA, 4(2): 873-892.

29. Nazira, M.S., Afza, T. 2018. Does managerial behavior of managing earnings mitigate the relationship between corporate governance and firm value? Evidence from an emerging market. Future Business Journal, 4(2018):139-156.

30. Obigbemi, I.F., Omolehinwa, E.O., Mukoro, D.O., Caleb, E.B., Olusanmi, O.A. 2016. Earnings Management and Board Structure: Evidence from Nigeria. SAGE, JulySeptember: 1-15.

31. Roychowdhury, S. 2006. Earnings Management through Real Activities Manipulation. Journal of Accounting and Economics, 42(3): 335-370.

32. Saleem, E., Alzoubi, S. 2016. Audit Quality and Earnings Management: Evidence from Jordan. Journal of Applied Accounting Research, 17(2):1-17.

33. Subekti, I. 2012. Accrual and Real Earnings Management: One of the Perspectives of Prospect Theory. Journal of Economics, Business, and Accountancy Ventura, 15(3): 443456.

34. Sun, L. 2012. Executive Compensation and Contract Driven Earnings Management. Asian Academy of Management Journal of Accounting and Finance AAMJAF, 8(2): 111127.

35. Surifah. 2011. Arranging The Index of Corporate Governance. Jurnal Dinamika Manajemen, 2(1): 1-16.

36. Sutedi, A. 2011. Good Corporate Governance. Jakarta: Sinar Grafika.

37. Vakilifard, H., Mortazavi, M. S. 2016. The Impact of Financial Leverage on Accrual-Based and Real Earnings Management. International Journal of Academic Research in Accounting, Finance and Management Sciences Vol. 6, No.2, April 2016, pp. 53-60

38. Vos, L.J.P,D. 2010. Equity Incentives and Earnings Management in The United Kingdom. Thesis. Erasmus University of Rotterdam.

39. Wang, X. 2014. New Evidence on Real Earnings Management: An International Investigation. PhD Thesis. Auckland University of Technology.

40. Wolk, H. I., Tearney, M. G., Dodd, J. L. 2001. Accounting Theory-A Conceptual and Institutional Approach 5/e. South-Western College Publishing. Ohio.

41. Watts, R., Zimmerman, J. 1978. Towards a Positive Theory of the Determination of Accounting Standards. The Accounting Review 53 (January):112-134. 